\title{
Developing Tri Hita Karana based Student Worksheet to Improve Primary School Students' Critical Thinking During Learning from Home
}

\author{
I Made Astra Winaya ${ }^{1 *}$ \\ 1 Universitas Dwijendra, Indonesia \\ *e-mail: astrawinayadwijendra@gmail.com
}

Article history: Received 15 December 2020; Accepted 31 March 2021; Available online 30 April 2021

\begin{abstract}
This study aimed at developing Tri Hita Karana based student worksheets to improve students' critical thinking skills. The model used in the development of Tri Hita Karana-based worksheets in this study was the ADDIE model (Analyze, Design, Development, Implementation, Evaluation). The results of this study revealed that the validity of the developed student worksheets was

Keywords:

Student Worksheet; Tri Hita Karana; Critical Thinking; Elementary School Students;

Learning from Home excellent. It was indicated by the average test scores of material and design experts which was about $83.75 \%$ and $81.58 \%$ and considered having very good quality. The readability test in class A and B obtained an average score of $82.27 \%$ and $80.64 \%$ with very good quality. The results also showed that the developed worksheets were able to improve students' critical thinking skills. This could be seen from the n-gain values in class A and B of 0.74 and 0.78 in the medium category, and the sig value. in the paired sample $t$ test of 0.00 in both classes. Teachers and students gave good responses to the developed worksheets. In conclusion, Tri Hita Karana based student worksheets with the feasibility and effectiveness in improving students' critical thinking skills were successsfully developed.
\end{abstract}

Copyright (® Universitas Pendidikan Ganesha. All rights reserved.

\section{Introduction}

The implementation of learning from home during the pandemic is a policy taken by the Ministry of Education and Culture to ensure the fulfillment of students' rights to get educational services during the Covid-19 emergency, protect education unit residents from the adverse effects of Covid-19, prevent the spread and transmission of Covid- 19 in education units and ensuring the fulfillment of psychosocial support for educators, students, and parents (Kemdikbud, 2020). Ideally, the implementation of learning from home can still accommodate the learning needs of students to develop talents and interests according to their education level (Arifa, 2020). In realizing learning from the ideal home, adequate human resources, appropriate curriculum, availability of learning resources, and support for devices and stable networks are needed so that communication between students and educators can run effectively.

In practice, learning from home is not entirely easy for students and teachers to practice. As a result, the Indonesian Child Protection Commission (KPAI) received complaints from a number of parents of students who complained about the assignments that teachers have distributed to their children online. Children are stressed because they get various tasks every day from their teachers. Based on the results of the needs analysis obtained through interviews with teachers and fourth grade students in two different elementary schools, namely: SD Negeri 1 Selanbawak and SD Negeri 2 Selanbawak, information was obtained that the teaching materials used by the teacher were textbooks and student worksheets. The worksheets used in schools are student worksheets made from one of the publishers in Indonesia which only 
contain material summaries, practice questions, no investigative activities and no activities that can train students' critical thinking skills. This is certainly further deterring the achievement of 21st century educational competencies.

Three 21st century education concepts have been adapted by the Ministry of Education and Culture of the Republic of Indonesia to develop curricula for primary to secondary school levels. The three concepts are 21st Century Skills (Trilling and Fadel, 2009), scientific approach (Dyer et al., 2009) and authentic learning and authentic assessment (Wiggins and Mc. Tighe, 2011). Furthermore, the three concepts were adapted to develop the 2013 Curriculum (K-13). This curriculum is expected to be able to form productive, creative, innovative, and affective Indonesians through strengthening integrated attitudes, skills and knowledge (Kemendikbud, 2014). The reasons for curriculum development according to the Ministry of Education and Culture (2014) are based on future challenges and competencies for students. The challenges referred to are: (1) globalization (WTO, ASEAN community, APEC, CAFTA), (2) environmental problems, (3) advances in information technology, (4) advances in science and technology, (5) knowledge-based economies, (6) revival of creative and cultural industries, (7) a shift in world economic power, (8) the influence and impact of technology, (9) quality, investment and transformation in the education sector, and (10) TIMSS and PISA materials. Meanwhile, the future competencies are: (1) ability to communicate, (2) ability to think clearly and critically, (3) ability to consider the moral aspects of a problem, (4) ability to be responsible citizens, (5) ability to try to understand and tolerate different views, (6) the ability to live in a globalized society, (7) have broad interests in life, (8) have readiness to work, (9) have intelligence according to their talents / interests, and (10) have a sense of responsibility for the environment.

The success of a learning process in achieving the expected goals cannot be separated from the various learning components used. One component that plays an important role in supporting the learning process is teaching materials in the form of worksheets. The definition of student worksheets according to Wulandari, Suliyanah, \& Rohmawati (2017) is a guide for students who are used to carry out investigations or solve problems. Student worksheets is made based on the structure of the student worksheets according to the Ministry of National Education (2008) consisting of several parts, namely: (1) title; (2) learning instructions (student instructions); (3) competencies to be achieved; (4) supporting information; (5) tasks and work steps; and (6) assessment.

The use of the concept of local wisdom, in this case the Tri Hita Karana concept, is very important in developing student worksheets. This is in line with the research conducted by (Winaya, A., Priantini, DW. AM, \& Widiastuti, 2018) that the application of interactive multimedia-based learning media with the Tri Hita Karana concept is effective in increasing the motivation for student learning outcomes because this learning media synergizes the method maintaining the harmony of human-human relations (pawongan), man with nature (palemahan) and man and God (Pahryangan). Learning activities like this will educate students to stick to the Tri Hita Karana concept which is believed by the community, especially the Balinese people, in maintaining harmonious relationships with fellow humans, nature and God so that learning becomes more meaningful.

This study aimed to develop worksheets based on Tri Hita Karana to determine the validity, practicality and effectiveness of Tri Hita Karana-based worksheets. The benefits of this research for teachers, namely student worksheets based on Tri Hita Karana, can be used by teachers as teaching materials in learning activities from home. And for students, this worksheet can be used to improve critical thinking skills. 


\section{Method}

This study was a research \& development (R\&D) which utilized mixed method design meaning that it combines the nature of both qualitative and quantitative at once. ADDIE (Analyze, Design, Development, Implementation, and Evaluation) model as proposed by Lee \& Owens (2004) was used during the development of this study. The Analyze stage is carried out to determine the potential and problems that may occur during study from home through direct interviews via WhatsApp calls and filling out questionnaires to teachers and students via Google Form. In the design stage, the developed students' worksheets framework was made based on the indicators to be achieved. The first draft of Tri Hita Karana based student worksheet was completed in this stage. Then, as the part of the development stage, validity testing was assisted by two Dwijendra University lecturers and a science teacher. It was done by filling out a material and design expert test questionnaire. The scoring criteria in the questionnaire used a Likert scale adapted from Ratumanan \& Laurent (2011). Each questionnaire consists of four answe choices (1) invalid, (2) less valid, (3) valid, and (4) very valid. In the implementation stage, practicality tests and effectiveness tests were conducted to 12 fourth grade students of SD Negeri 1 and 2 Selanbawak by using two classes: experimental class one (A) and experimental class two (B). The validity test was done by filling out a material and design expert test questionnaire. The practicality test was done by filling out a legibility test questionnaire. The effectiveness test was carried out by filling in the pretest and posttest questions.

The evaluation stage could be carried out in each of the four stages which aims to measure the feasibility of the developed student worksheets. The data were collected by using interview guide and questionnaire facilitated by google form. The data obtained from the interview was analyzed by using descriptive analysis technique, namely by narrating the results of the interview. The data of questionnaire responses were analyzed by using percentage analysis based on the formula according to Sudjana (2005) as follows:

$$
\% X=\frac{\sum \text { obtained score }}{\sum \text { maximum score }} x 100 \%
$$

The improvement on students' critical thinking skills could be seen from the value of n-gain of pre-test and post-test score as calculated by using the following formula.

$$
N-\text { gain }=\frac{\text { skor posttes }- \text { skor pretest }}{\text { skormaksimum }- \text { skor petest }}
$$

The result of N-Gain calculation could be further interpreted by using criteria proposed by Hake (2002) as seen on Table 1.

Tabel 1. N-gain Interpretation Criteria

\begin{tabular}{ll}
\hline N-gain & Interpretation Criteria \\
\hline$N-$ gain $\geq 0,7$ & High \\
$0,3 \leq N-$ gain $<0,7$ & Average \\
$N-$ gain $<0,3$ & Low \\
\hline
\end{tabular}

Hypothesis testing, which was facilitated by paired sample $t$ test, was done to investigate the improvement on students' critical thinking skills after using the developed product. The testing 
was assisted by SPSS 22. The hypotheses were: HO: there was no improvement on students' critical thinking skills after using Tri Hita Karana based student worksheets; H1: there was an improvement on students' critical thinking skills after using Tri Hita Karana based student worksheets. According to Arikunto (2011, p. 120), (1) H1 would be accepted if sig. value $\leq 0,05$; (2) H1 would be rejected if sig.value $\geq 0,05$.

\section{Result and Discussion}

The research results obtained in the study are students worksheet based on Tri Hita Karana. Activities in the student worksheet consist of observing, asking, trying, associating, and communicating. These stages are the stages of the scientific approach in the 2013 curriculum and at each stage are designed to improve students' critical thinking skills. The learning approach with the help of Tri Hita Karana-based worksheets makes students active in learning with an interest in subject matter by observing and understanding phenomena so that students' critical thinking skills can grow and develop. Revealing daily phenomena related to the earth and the universe and asking questions about these phenomena can increase students' enthusiasm for learning.

The developed worksheets have been tested for validity and legibility tests. The validity test was carried out by two lecturers at Dwijendra University and a grade IV teacher by filling out a test questionnaire for media and design experts. The results of the material and media expert test can be seen in Table 2 .

Table 2. Material Expert Test Results

\begin{tabular}{llcl}
\hline No. & \multicolumn{1}{c}{ Aspects Assessed } & $\begin{array}{c}\text { Examiner } \\
\text { Score }\end{array}$ & Statement of Quality \\
\hline 1 & $\begin{array}{l}\text { Conformity of Students } \\
\text { Worksheet Material Content }\end{array}$ & $83,75 \%$ & Very high validity \\
2 & Construction worksheets & $81,58 \%$ & Very high validity \\
\hline
\end{tabular}

Based on the results of the material expert test, the average score on the suitability of the material content was $83.75 \%$ and the student worksheet construction aspect was $81.58 \%$ with very high validity categories.

The material in the student worksheet based on Tri Hita Karana obtained very good criteria because the material was adapted to the theme of the earth and the universe in grade IV SD. The feasibility of the material on the worksheets is also adjusted to the suggestions for improvement given by the validator. In Table 4 below, the results of the media test will be presented.

Table 3. Media Expert Test Results

\begin{tabular}{llll}
\hline No. & Aspects Assessed & Examiner Score & Statement of Quality \\
\hline 1 & Cover students worksheet & $82,27 \%$ & Very high validity \\
2 & Fill in the worksheets & $80,64 \%$ & Very high validity \\
\hline
\end{tabular}

Based on the media test questionnaire, the average score on the students worksheet cover aspect is obtained $82.27 \%$ with very high validity category. The very high validity category on the students worksheet cover aspect is obtained from suggestions for improvement given by the validator. The average score obtained on the content aspect of the worksheets is $80.64 \%$ with a 
very high validity category. The very high validity category in the content aspect of the students worksheet was obtained from suggestions for improvement given by the validator. The worksheets are designed as attractive as possible and are used in groups. The design of the worksheets is attractive and is equipped with pictures as illustrations so that it is not monotonous so that it can attract students' interest in learning the worksheets (Septiani, Ridlo, \& Setiati, 2013).

The researcher also conducted a legibility test using two classes, namely the experimental class one (A) and the experimental class two (B). The readability test was carried out by filling out a questionnaire conducted by 12 students in classes A and B. The readability test results can be seen in Table 4 .

Table 4. Readability Test Results

\begin{tabular}{l|l|l|l|l|l}
\hline \multirow{2}{*}{ No. } & \multirow{2}{*}{ Aspects Assessed } & \multicolumn{2}{c}{ Class Examiners Score } & \multicolumn{2}{c}{ Class Quantitative Statement } \\
\cline { 3 - 6 } & & $\mathbf{A}$ & $\mathbf{B}$ & $\mathbf{A}$ & $\mathbf{B}$ \\
\hline $\mathbf{1}$ & Attractiveness & $81,55 \%$ & $77,6 \%$ & Very good & Good \\
\hline $\mathbf{2}$ & Ease of use & $83,33 \%$ & $80,21 \%$ & Very good & Very good \\
\hline $\mathbf{3}$ & Usefulness of Use & $\mathbf{8 1 , 9 4 \%}$ & $\mathbf{8 4 , 0 3}$ & Very good & Very good \\
\hline
\end{tabular}

Based on the readability test questionnaire in class $\mathrm{A}$, it was found that the average score on the attractiveness aspect was $81.55 \%$ in the very good category. The average score obtained on the ease of use of the student worksheet was $83.33 \%$ with the very good category. The average score obtained on the usefulness aspect of using student worksheet was $81.94 \%$ with the very good category. The readability test questionnaire in class B obtained an average score on the attractiveness aspect of $77.68 \%$ with a good category. The average score obtained in the aspect of ease of use of the student worksheet was $80.21 \%$ with the very good category. The average score obtained on the benefit aspect of using student worksheet was $84.03 \%$ with the very good category.

The effectiveness test was carried out on 12 students in class A and 12 students in class $\mathrm{B}$ by giving the same treatment. The test is carried out based on the pretest and posttest scores of each student. Based on the results of the pretest and posttest answers, it is known that there are some students who do not experience an increase in questions number 2,3 , and 7 . Students who do not experience improvement because they do not understand the problems in the questions and students are not familiar with questions C4 - C6. Students must often be trained continuously to work on C4 - C6 questions so that students can improve their critical thinking skills. Critical thinking skills, namely abilities that are not inherited from parents or are innate, but abilities that need to be trained gradually and continuously (Sarjono, 2017).

The data from the pretest and posttest answers were then analyzed to determine the increase in students' critical thinking skills using $\mathrm{N}$-gain. The N-gain results can be seen in Table 5.

Table 5. N-gain results

\begin{tabular}{llllllll}
\hline \multicolumn{1}{l}{ Score } & \multicolumn{5}{l}{ Score N-gain class } & \multicolumn{2}{l}{ Class Criteria } \\
\cline { 1 - 5 } Pretest class & \multicolumn{2}{l}{ Posttest classs } & & & \\
\hline A & B & A & B & A & B & A & B \\
\hline 43,33 & 41,95 & 85,00 & 87,22 & 0,74 & 0,78 & Moderate & Moderate \\
\hline
\end{tabular}


Based on the $\mathrm{N}$-gain value with the help of Microsoft Excel, the $\mathrm{N}$-gain value is 0.74 with moderate criteria in class A and 0.78 with moderate criteria in class B. Based on the N-gain value obtained, it can be concluded that the student worksheet has been valid able to improve students' critical thinking skills.

Hypothesis testing was carried out using the data from the students' pretest and posttest using the paired sample $t$ test. with the help of the SPSS 22 program. Based on the paired sample $t$ test in classes A and B, the sig value is obtained. of 0.00 , which means that there is an increase in students' critical thinking skills after using the Tri Hita Karana based worksheets. This can be seen in the sig value. obtained $<0.05$ so that $\mathrm{H} 1$ is accepted. The average increase in critical thinking skills in class A is 41.67 and 45.27 in class B.

\section{Conclusion}

Based on the research that has been done, it is concluded that the student worksheets developed are valid, practical, and effective in improving students' critical thinking skills. This can be seen from the results of the validity test, the $\mathrm{N}$-gain value, and the paired sample t test. Based on the results of research that has been conducted, the researcher suggests that teachers are expected to develop Tri Hita Karana based student worksheets on other themes that are in accordance with their characteristics, so that they can achieve learning objectives. This product development should be tested on a large scale..

\section{References}

Arikunto, S. (2011). Prosedur Penelitian Suatu Pendekatan Praktek. Jakarta: Bumi Aksara.

Depdiknas. (2008). Panduan Penyusunan Kurikulum Tingkat Satuan Pendidikan. Jakarta: Depdiknas.

Kemdikbud. 2020. Kemendikbud Terbitkan Pedoman Penyelenggaraan Belajar dari Rumah. Tersedia pada https://www.kemdikbud.go.id/main/blog/2020/05/kemendikbudterbitkan-pedoman-penyelenggaraan-belajar-dari-rumah. di Unduh pada 9 Oktober 2020

Khanasta, I., Sinon, I. L. S., \& Widyaningsih, S. W. (2016). Penerapan Model Pembelajaran Berbasis Fenomena Menggunakan Metode Demonstrasi terhadap Berpikir Kritis Peserta Didik Kelas XI IPA SMA Yapis Manokwari. Wahana Didakti, 14(3), 14-27.

Lee, W. W., \& Owens, D. L. (2004). Mulitmedia Based.

Ratumanan, T.G., \& Laurent, T. (2011). Penilaian Hasil Belajar pada Tingkat Satuan Pendidikan (2nd ed.). Surabaya: Unesa University Press.

Sarjono. (2017). Internalisasi Berpikir Kritis dalam Pembelajaran Fisika. Jurnal Madaniyah, 7(2), 343-353.

Sudjana. (2005). Metode Statistika (6th ed.). Bandung: PT. Tarsito.

Winaya, A., Priantini, DW. A. M., \& Widiastuti, N. K. (2018). Pengembangan Media Pembelajaran Berbasis Multimedia Interaktif Dengan Konsep Tri Hita Karana Untuk Pembelajaran Tematik di SD Kelas III Gugus 6 Kecamatan Abiansemal, Badung, Bali. Jurnal Kajian Pendidikan: Widya Accarya, 9(1), 1-14. https://doi.org/10.19016 /jcshokuriku.3.0_1.

Winaya, I Made Astra. (2020). Pembelajaran Daring Yang Efektif Sebagai 'New Normal' Sekolah Di Tengah Pandemi Covid-19. Book Chapter Covid-19: Persepektif Pendidikan. Yayasan Kita Menulis. 